\title{
PEMODELAN BISNIS DENGAN IMPLEMENTASI CUSTOMER DEVELOPMENT MODEL PADA M-BUSINESS STARTUP TERAMPIL
}

\author{
Tristiyanto $^{1)}$, Anie Rose Irawati' ${ }^{2)}$, Kurnia Muludi ${ }^{3)}$, Tantut Wahyu Setyoko ${ }^{4)}$ \\ 1,2,3,4 Ilmu Komputer, Universitas Lampung \\ 1,2,3,4 Jalan Soemantri Brojonegoro No. 1 Gedung Meneng, Bandar Lampung \\ Email: ${ }^{1}$ tristiyanto.1981@fmipa.unila.ac.id, ${ }^{2}$ an.irawati@gmail.com, ${ }^{3}$ kmuludi@yahoo.com, \\ ${ }^{4}$ tantut.wahyu1001@students.unila.ac.id
}

\begin{abstract}
Terampil is a form of tangible contribution to supporting the vision of the Indonesian government in the 2019-2024 period, namely creating superior human resources and achieving Indonesia's progress through providing access to skills and professional certification. The need for comprehensive business modeling of the realization of the solution is needed so that it can be clearly visualized, assessed, and validated based on the requirements of specific prospective users. Modeling of startup candidates for skilled business needs to be analyzed appropriately so that skilled can be commercialized globally. This study uses a customer development model or CDM approach to analyze and determine business modeling based on problems faced by specific potential users. User needs are obtained by conducting direct interviews, then the business modeling process is carried out with Lean Canvas through lowering the formulation of solutions for user needs. This approach is implemented through two stages, the stage of customer discovery and the stage of customer creation. The stages of customer discovery generate facts about potential user problems that are used to form value proportions. Whereas the customer creation stage is carried out gathering user needs. The formulation of the developed business model is then validated through expert judgment to get an assessment. Based on expert judgment, it is known that Skilled business modeling is in accordance with the needs of specific prospective users. However, a renewal of features and a more detailed analysis of the feasibility study is needed to complete this skilled business development analysis.
\end{abstract}

Keyword : customer discovery; customer creation; customer development model; lean canvas; value proporsition

\begin{abstract}
Abstrak
Terampil adalah bentuk kontribusi nyata untuk mendukung visi pemerintah Indonesia periode 2019-2024 yaitu menciptakan sumber daya manusia yang unggul dan mencapai kemajuan Indonesia melalui penyediaan akses keterampilan dan sertifikasi profesional. Kebutuhan pemodelan bisnis yang komprehensif terhadap realisasi solusi tersebut diperlukan agar dapat divisualisasikan, dinilai, dan divalidasi dengan jelas berdasarkan persyaratan calon pengguna spesifik. Pemodelan calon rintisan startup bisnis Terampil perlu dianalisis secara tepat sehingga Terampil dapat dikomersialisasi secara global. Penelitian ini menggunakan pendekatan customer development model atau CDM untuk menganalisis dan menentukan pemodelan bisnis berdasarkan permasalahan yang dihadapi oleh calon pengguna spesifik. Kebutuhan pengguna diperoleh dengan melakukan wawancara langsung, kemudian proses pemodelan bisnis dilakukan dengan Lean Canvas melalui menurunkan rumusan solusi untuk kebutuhan pengguna. Pendekatan ini diimplemetasikan melalui dua tahap, tahapan customer discovery dan tahapan customer creation. Tahapan customer discovery menghasilkan fakta permasalahan calon pengguna yang digunakan untuk membentuk value proporsition. Sedangkan pada tahapan customer creation dilakukan pengumpulan kebutuhan pengguna. Perumusan model bisnis yang dikembangkan kemudian divalidasi melalui penilaian ahli untuk mendapatkan penilaian. Berdasarkan expert judgement diketahui bahwa pemodelan bisnis Terampil telah sesuai dengan kebutuhan calon pengguna spesifik. Namun, pembaharuan fitur serta analisis studi kelayakan yang lebih rinci sangat dibutuhkan untuk melengkapi analisis pengembangan bisnis Terampil ini.
\end{abstract}

Kata Kunci: customer discovery; customer creation; customer development model; lean canvas; value proporsition

\section{Pendahuluan}

Sumber Daya Manusia atau SDM Unggul, Indonesia Maju merupakan visi pemerintahan Republik Indonesia periode 2019-2024 [1]. Pengembangan sumber daya manusia dapat dilakukan melalui penanaman intelectual asset yang akan menjadi faktor pendukung produktivitas dan keunggulan kompetitif bagi individu yang memilikinya [2]. Salah satu upaya untuk melakukannya adalah dengan menerapkan proses pendidikan keterampilan hingga sertifikasi profesi [2]. Sertifikasi profesi dapat menjadi salah satu bukti yang menguatkan bahwa individu tersebut memiliki keunggulan yang kompetitif dan dapat dijadikan dasar untuk mendapatkan kerja yang layak [3]. 
Saat ini, per Februari 2019 keadaan ketenagakerjaan di Indonesia menunjukkan terdapat $5.01 \%$ atau 6.820 .000 orang dalam keadaan menganggur yang didominasi oleh lulusan Sekolah Menengah Kejuruan dan Perguruan Tinggi [4]. Sementara hanya terdapat $2,5 \%$ tenaga kerja yang memiliki sertifikasi profesi [5]. Dominasi angka pengganguran yang ada disebabkan karena belum tertanamnya intelectual asset sehingga tidak dapat menerapkan ilmu yang telah didapat selama mengenyam pendidikan, dan tidak dapat bersaing secara kompetitif. Persaingan global secara kompetitif juga akan dirasakan oleh generasi penerus bangsa karena adanya bonus demografi pada 2030-2040 [6]. Kondisi ini menunjukkan bahwa jumlah usia produktif akan lebih mendominasi dibandingjkan dengan jumlah usia non-produktif [6]. Agar visi pemerintahan berkelanjutan, maka keberlimpahan ini harus dimanfaatkan dengan sangat baik.

Salah satu solusi untuk permasalahan tersebut dengan menyediakan akses pendidikan keterampilan dan sertifikasi profesi yang mudah dan tepat. Terampil merupakan usulan marketplace kursus keterampilan dan sertifikasi profesi berbasis andorid yang digunakan sebagai sarana belajar mengajar keterampilan. Realisasi solusi terhadap permasalahan tersebut dilakukan melalui pembuatan Terampil yang menyediakan fitur utama seperti kursus, diskusi online, dan pendaftaran sertifikasi profesi. Selain itu, Terampil dapat menghubungkan instruktur keterampilan dan peserta kursus. Hingga lembaga sertifikasi profesi mitra Terampil

Kebutuhan pemodelan bisnis secara komprehensif pada pengembangan Terampil, sangat dibutuhkan karena marketplace akan dibangun berdasarkan kebutuhan pengguna. Selain itu, pemodelan bisnis dibuat sebagai upaya tindak lanjut bisnis melalui perencanaan hingga proses pembuatan model bisnis berdasarkan kebutuhan pengguna. Sehingga usulan pemodelan bisnis dapat digunakan untuk implementasi pengembangan Terampil untuk pembaharuan fitur dan pemodelan bisnis yang tepat sesuai dengan harapan pengguna.

Customer Development Model atau CDM merupakan suatu pendekatan yang dapat digunakan untuk memudahkan pebisnis pemula. Pendekatan CDM akan dihasilkan pemahaman terkait kebutuhan pelanggan dan permasalahan yang dialaminya [7]. Kerangka kerja sederhana CDM dapat memberikan desain solusi berdasarkan pada permasalahan yang telah didapat berdasarkan informasi calon pelanggan [8]. Penelitian deskripstif dengan pndekatan kualitatif yang telah dilakukan oleh [9] mengenai penerapan model bisnis mempengaruhi ristisan bisnis startup Talangin, penerapan model bisnis Talangin sangat mudah diterapkan karena Talangin dibuat dengan pendekatan calon pengguna serta mengutamakan kebutuhan pengguna dalam pengembangannya.

Pendekatan yang banyak diterapkan pada bisnis startup berbasis produk teknologi ini memiliki empat tahapan [7]. Tahapan CDM terbagi atas beberapa tahap yaitu customer discovery, customer validation, customer creation, dan company building [8]. Keempat tahapan CDM akan digunakan untuk menciptakan model bisnis berdasarkan kebutuhan yang telah didapatkan. Penelitian yang telah dilakukan oleh [10] hanya menggunakan tahapan customer discovery. Namun, penelitian ini menggunakan dua tahapan yaitu customer discovery dan customer creation tahapan CDM pada m-business startup Terampil.

Penelitian ini memberikan gambaran bahwa CDM dapat digunakan sebagai pendamping pengembangan produk melalui tahapan yang disediakan [8]. Sehingga hasil yang didapat pada penelitian ini adalah solusi pengembangan produk yang memiliki keterbaharuan berdasarkan pemasalahan yang dijadikan kebutuhan pengguna, pengembangan model bisnis dengan lean canvas, dan rekomendasi kepada company agar dapat menerapkan keterbaharuan yang telah didapatkan.

\section{Metode Penelitian}

\section{a. Kerangka Penelitian}

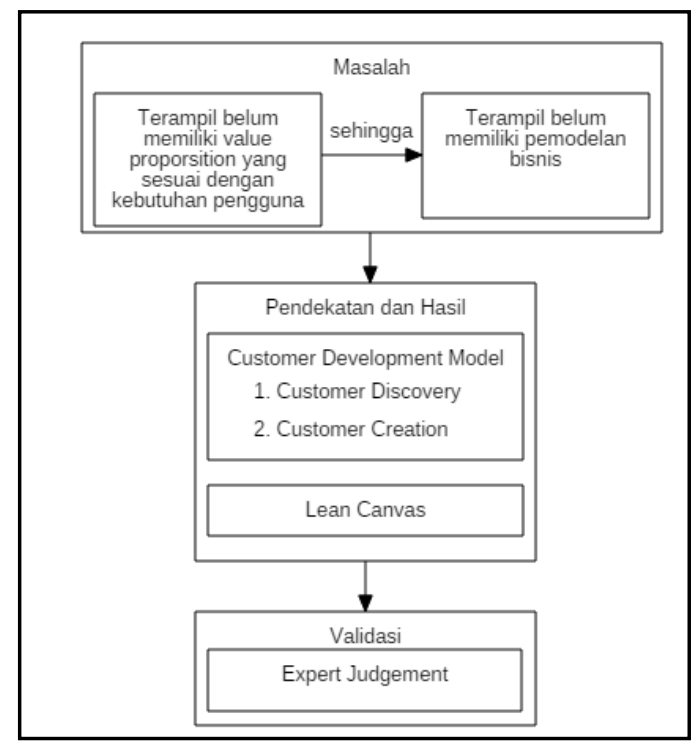

Gambar 1. Kerangka Kerja Penelitian.

Kerangka kerja seperti pada gambar 1 menjelaskan tentang alur penelitian ini. Penelitian berawal dari sebuah masalah yaitu m-business startup Terampil belum memiliki value proporsition yang cukup memenuhi kebutuhan pengguna sehingga belum memiliki penggambaran model bisnis yang jelas. Identifikasi dilakukan dengan menggunakan dua tahapan pada customer development model yaitu customer discovery dan customer creation. Customer discovery digunakan untuk mendapatkan pemasalahan dan kebutuhan agar dapat dijadikan value proporsition yang sesuai. Sementara customer creation digunakan untuk mendapatkan pemodelan bisnis dengan cara melakukan penurunan terhadap sembilan blok bangunan lean canvas. Tahapan validasi model bisnis dilakukan melalui expert judgement yaitu dengan meminta pendapat terhadap model bisnis dan startegi pemasaran yang telah diusulkan. 


\section{b. Pendekatan Customer Development Model}

Pendekatan customer development model atau CDM banyak digunakan pada pengembangan bisnis startup berbasis teknologi [7]. Pendekatan ini memiliki empat tahapan inti yang fokusnya pada masalah yang dijadikan kebutuhan calon pengguna, karena CDM bukanlah suatu penggantian produk tetapi pendamping untuk memperbaiki produk [8].

Pendekatan customer development model memiliki empat tahapan inti yaitu, customer discovery, customer validation, customer creation dan building company. Tahapan ini dapat digunakan secara keseluruhan atau digunakan salah satunya saja. Tahapan customer validation dapat digunakan apabila produk bisnis sudah memiliki data pengguna yang dapat diolah menggunakan teknik statistik. Sementara tahapan building company dapat digunakan ketika suatu organisasi telah membangun perusahaannya dan akan mengupgrade perusahaannya. Penelitian ini menggunakan dua tahapan yaitu customer discovery dan customer ceation.

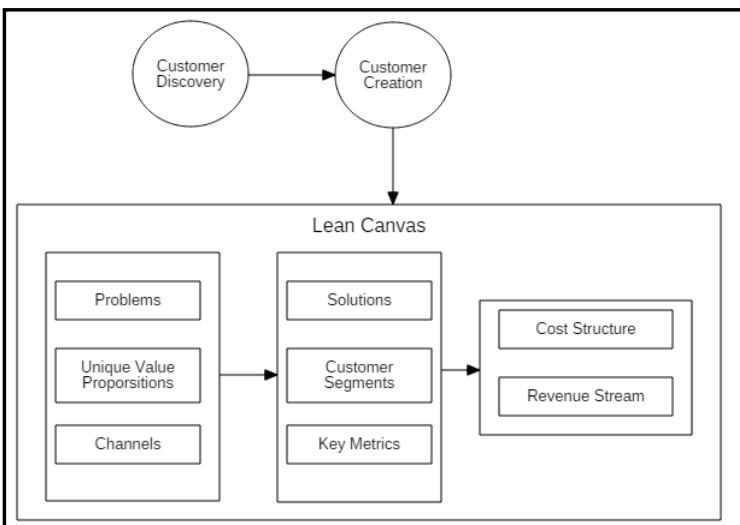

Gambar 2. Pendekatan Customer Development Model untuk Pemodelan Bisnis Terampil.

\section{Customer Discovery}

Customer discovery adalah tahapan yang digunakan untuk menemukan pelanggan yang akan menggunakan produk dan memastikan bahwa solusi yang ditawarkan merupakan hal yang penting bagi mereka Tahapan ini, pengembang harus melakukan survey terhadap calon pengguna secara spesifik untuk mendapatkan permasalahan yang dihadapi. Hasil yang didapatkan digunakan untuk menentukan value proporsition pada perbaikan produk bisnis [8]

Pada tahapan ini, dilakukan pendekatan terhadap calon pelanggan spesifik yang akan mengunakan Terampil. Langkah ini digunakan untuk mengetahui permasalahan dan kebutuhan yang dihadapi oleh calon pengguna. Tahapan ini digunakan sebagai acuan dalam pembentukan unique value proporsition pada penggambaran model bisnis dengan cara melakukan penjabaran faktor temuan dan analisis usulan berdasarkan hasil pendekatan.

Pendekatan dilakukan di SMK BLK Bandar Lampung dan Kursus Keterampilan DCreate Academy dengan mewawancarai Direktur LSP SMK BLK Bandar Lampung, peserta kursus keterampilan SMK BLK Bandar Lampung, dan instruktur keterampilan DCreate Academy untuk mendapatkan informasi terkait permasalahan dan kebutuhan saat ini. Pemilihan informan didasari pada teori pendekatan yaitu melakukan tinjauan langsung terhadap pengguna secara spesifik.

\section{Customer Creation}

Tahapan ini memiliki tujuan untuk menciptakan value proporsition atau menangkap keinginan pelanggan terhadap produk bisnis yang ditawarkan. Value proporsition dibuat agar pelanggan menjadi setia dan memungkinkan akan mendapatkan pelanggan baru [7]. Setelah tahapan ini akan dibagun pemodelan bisnis dengan memanfaatkan lean canvas.

Pada tahapan ini, penurunan hasil analisis permasalahan dilakukan dengan penerjemahan keinginan pelanggan terhadap Terampil. Tahapan ini memperlihatkan value proporsition berdasarkan pada tahapan customer discovery yang telah dilakukan. Customer creation menjadi acuan dalam pembuatan model bisnis Terampil melalui penggambaran dengan lean canvas.

\section{Lean Canvas}

Lean Canvas merupakan hasil adopsi dari bisnis model kanvas [11]. Bisnis model kanvas merupakan bahasa yang dapat digunakan secara bersama untuk menggambarkan, memvisualisasikan, menilai, hingga melakukan perubahan terhadap model binis melalui sembilan blok bangunan yang tersedia [12]. Lean canvas digunakan sebagai pendamping dalam perencanaan bisnis karena melalui lean canvas dilakukan dokumentasi model bisnis, pengukuran kemajuan bisnis, dan komunikasi terhadap stakeholder yang berkepentingan secara internal ataupun eksternal [11]

Tahapan pembuatan model bisnis dengan lean canvas dilakukan secara bertahap berdasarkan pada analisa faktor temuan yang telah didapatkan pada bagian customer creation. Pembuatan lean canvas dilakukan secara bertahap atau sesuai dengan turunannya. Pada tingkatan pertama dijelaskan problems, unique value proporsition, dan channels. Selanjutnya pada tingakatan kedua dijelaskan terkait solutions, customer segments, dan key metrics. Kemudian, tingkatan terakhir adalah menentukan cost structure dan revenue streams untuk Terampil.

\section{c. Validasi Expert}

Validasi pemodelan bisnis dilakukan oleh expert atau ahli yaitu Dr. Sri Ratna Sulistiyanti, M.T. Validasi pemodelan bisnis menjelaskan kesesuaian pemodelan bisnis Terampil berdasarkan analisa temuan permasalahan yang telah dilakukan pada tahapan customer discovery hingga mengahasilkan model bisnis pada bagian customer creation dengan lean canvas. Validasi ini juga merupakan penilaian kelayakan pemodelan bisnis yang akan diterapkan sesuai dengan kebutuhan pengguna yang telah 
didapatkan. Pemodelan bisnis yang baik akan mengikuti konsep bisnis melalui proyeksi bisnis yang relevan.

\section{Hasil dan Analisis}

\section{a. Pendekatan Customer Development Model}

\section{Customer Discovery}

Pada tahapan customer discovery didapatkan hasil berupa temuan permasalahan pelanggan berdasarkan informasi hasil wawancara. Wawancara dilakukan dengan menemui target pengguna spesifik, yaitu seorang direktur LSP SMK BLK Bandar Lampung, sembilan pelajar keterampilan, dan tiga orang instruktur keterampilan. Berdasarkan hasil wawancara yang telah dilakukan, didapatkan beberapa temuan berupa permasalahan yang dijadikan sebagai bahan dalam menentukan kebutuhan produk Terampil. Hasil yang didapatkan pada tahapan ini juga dijadikan sebagai value proporsition Terampil, serta menjadi acuan dalam pemodelan bisnis Terampil.

Tabel 1 berikut ini menjelaskan secara umum hasil temuan permasalahan perobjek yang didapatkan berdasarkan wawancara bersama calon pengguna spesifik.

Tabel 1. Temuan Masalah dengan Customer Discovery

\begin{tabular}{|c|c|c|}
\hline No & $\begin{array}{l}\text { Calon } \\
\text { Pelanggan } \\
\end{array}$ & Temuan Masalah \\
\hline \multirow{4}{*}{1} & \multirow{4}{*}{ Pengelola LSP } & $\begin{array}{l}\text { Kesulitan penerimaan } \\
\text { pendaftaran }\end{array}$ \\
\hline & & $\begin{array}{l}\text { Kebutuhan } \\
\text { pendampingan asesor uji }\end{array}$ \\
\hline & & $\begin{array}{l}\text { Platform uji sertifikasi } \\
\text { profesi yang belum } \\
\text { memadai }\end{array}$ \\
\hline & & $\begin{array}{l}\text { Pemberitaan } \\
\text { pengumuman uji } \\
\text { sertifikasi masih } \\
\text { konvensional }\end{array}$ \\
\hline \multirow{3}{*}{2} & \multirow{3}{*}{ Peserta kursus } & $\begin{array}{l}\text { Keterbatasan waktu } \\
\text { dalam pembelajaran } \\
\text { keterampilan disekolah }\end{array}$ \\
\hline & & $\begin{array}{l}\text { Akses pendidikan } \\
\text { keterampilan jarak jauh } \\
\text { sesuai kurikulum } \\
\text { pembelajaran belum } \\
\text { tersedia secara } \\
\text { komprehensif }\end{array}$ \\
\hline & & $\begin{array}{l}\text { Biaya kursus secara } \\
\text { langsung relatif lebih } \\
\text { mahal }\end{array}$ \\
\hline 3 & Instruktur & $\begin{array}{l}\text { Gaji yang diterima } \\
\text { belum sepadan dengan } \\
\text { jam mengajar }\end{array}$ \\
\hline
\end{tabular}

Kebutuhan platform yang dapat memperdalam ilmu pengetahuannya

Kebutuhan akses sertifikasi kompetensi dan profesi

Selain untuk dijadikan usulan pemodelan bisnis Terampil, hasil yang telah didapatkan digunakan juga dalam penambahan fitur untuk pengembangan Terampil. Berdasarkan hasil yang telah didapat pada tahapan ini, terlihat jelas kebutuhan pengguna berdasarkan permasalahan yang dialami saat ini.

Pengelola LSP membutuhkan sistem yang dapat digunakan untuk uji sertifikasi profesi diawali dengan proses pendaftaran, pendampingan asesor uji untuk mendapatkan kurikulum yang uptodate hingga proses uji sertifikasi yang berlangsung.

Peserta kursus membutuhkan akses pendidikan keterampilan dapat dilakukan jarak jauh dengan biaya yang lebih terjangkau. Namun, ada penyesuaian kurikulum pembelajaran dengan pembelajaran yang dilakukan.

Selain menginginkan sebuah platform yang dapat digunakan untuk mendapatkan akses pendidikan keterampilan lanjutan, instruktur keterampilan juga menginginkan pendapatan yang dihasilkan melalui pengajaran pendidikan keterampilan sepadan dengan pengajaran yang dilakukan.

\section{Customer Creation}

Pada tahapan customer creation dilakukan penangkapan keinginan calon pelanggan spesifik terhadap produk bisnis yang ditawarkan. Pada tahapan ini, temuan permasalahan berupa fakta permasalahan yang dihadapi oleh calon pengguna spesifik yang telah diterima pada tahapan sebelumnya digunakan untuk pembentukan value proporsition. Hal ini ditujukkan agar calon pengguna menggunakan produk bisnis yang ditawarkan dan setia dalam penggunaannya. Hasil yang telah didapatkan pada tahapan ini berupa value proporsition yang digunakan dalam penyusunan model bisnis dengan menggunakan lean canvas secara bertahap dan berkesinambungan satu dengan yang lain

Hasil penurunan analisis permasalahan didapatkan dari tahapan cutomer discovery dan digunakan untuk pemodelan bisnis. Penjelasan turunan hasil permasalahan berikut ini menggunakan analisis pemodelan sembilan blok bangunan lean canvas beserta solusi yang digunakan sebagai value proporsition.

\section{Problems atau Permasalahan}

Blok yang berisi informasi permasalahan yang menjadi latar belakang pembangunan bisnis. 


\section{a. Fakta Permasalahan}

Berdasarkan informasi narasumber yang telah didapatkan, tabel 2 telah menjelasakan permasalahan yang saat ini dihadapi oleh calon pelanggan Terampil.

\section{b. Solusi}

Marketplace pendidikan keterampilan dan sertifikasi profesi yang menyediakan akses pendidikan keterampilan secara mudah dan hemat serta akses uji sertifikasi profesi

\section{Unique Value Proporsition atau Proporsisi Nilai} Unik

Blok yang berisi informasi dead center karena berisi esensi produk yang ditawarkan kepada pengguna.

\section{a. Fakta Permasalahan}

Berdasarkan permasalahan perlu adanya pembaharuan Terampil agar pelanggan dapat selalu menggunakan marketplace yang diusulkan

\section{b. Solusi}

Rekomendasi unique value proporsition yang diberikan adalah sebagai berikut:

1. Kursus keterampilan dengan KKNI

2. Diskon pembelajaran

3. Freemium

4. Konsultasi online

5. Aplikasi berbahasa Indonesia

\section{Channels atau Saluran}

Blok yang berisi informasi cara untuk menjangkau segmen pelanggan untuk mendapatkan unique value proporsition

\section{a. Fakta Permasalahan}

Saluran yang diusulkan dapat berupa saluran secara online dan offline, melalui saluran diharapkan pengembangan bisnis akan lebih mudah sehingga dapat membantu mewujudkan key metrics atau harapan tim pengembang Terampil.

\section{b. Solusi}

\section{Saluran Online}

1. Ads Sosial Media

2. Rate Aplikasi

Saluran Offline

1. LSP Mitra

2. Pameran Startup

3. Alumni

4. Pamflet

5. LKK

6. Perusahaan Mitra

\section{Solution atau Solusi}

Blok yang berisi informasi solusi yang ditawarkan terhadap permasalahan yang dihadapi.

\section{a. Fakta Permasalahan}

Penyediaan solusi dapat menyesaikan masalah pada tabel 2. Solusi pada blok ini dibuat berdasarkan analisis permasalahan yang dilakukan dengan menggunakan customer development approach.

\section{b. Solusi}

1. Kursus keterampilan online dan offline serta pelatihan nasional

2. Marketplace uji sertifikasi profesi

3. Diskusi online

\section{Customer Segment atau Segmen Pelanggan}

Blok yang berisi informasi kelompok orang yang akan dijadikan target pengguna.

\section{a. Temuan}

Segmen pelanggan spesifik telah didapatkan pada tahapan customer discovery

\section{b. Solusi}

Segmen pelanggan Terampil sebgai berikut:

1. Unsilled dan Skilled People

2. Lembaga Sertifikasi Profesi dan Lembaga Kursus Keterampilan

3. Instruktur Keterampilan

4. Pelajar SD, SMP, SMA/K dan Perguruan Tinggi

\section{Key Metrics atau Metrik Kunci}

Blok yang berisi informasi harapan yang ditujukan untuk produk terhadap segmen pelanggan, arus pendapatan, dan permasalahan.

\section{a. Fakta Permasalahan}

Saluran yang diusulkan membantu pengembangan bisnis. Sehingga pada key metrics harapan untuk Terampil dapat didefinisikan

b. Solusi

1. Peningkatan pengguna dalam satu tahun pertama yaitu 500 peserta kursus, 100 instruktur keterampilan, dan 20 LSP mitra

2. Valuasi Terampil pada tahun pertama mencapai Rp300.000.000,00/th

3. Terdapat lima cabang Terampil

4. Adanya kontrol kualitas atau quality control terhadap pengembangan produk bisnis Terampil.

\section{Cost Structure atau Struktur Biaya}

Blok yang berisi informasi keseluruhan komponen biaya yang digunakan pada pengembangan produk bisnis. 


\section{a. Fakta Permasalahan}

Penyusunan cost structure didasarkan pada variable cost dan fixed cost yang dibutuhkan dalam pengembangan proyek bisnis Terampil

\section{b. Solusi}

Berikut ini adalah cost structure yang dibutuhkan.

Variable Cost

a. Promosi Digital

b. Biaya $\mathrm{RnD}$

Fixed Cost

1. Hosting

2. Domain

3. Google API

4. Pengujian Sistem

5. Server

6. Sewa Gedung

7. Gaji Karyawan

8. Perawatan Sistem

\section{Revenue Stream atau Arus Pendapatan}

Blok yang berisi informasi upaya organisasi bisnis dalam mendapatkan feedback berupa uang untuk keberlanjutan produk

\section{a. Fakta Permasalahan}

Penyusunan revenue melalui perhitungan BEP, NPV dan ROI terhadap asumsi biaya proyek bisnis Terampil

\section{b. Solusi}

Berdasarkan perhitungan asumsi pendapatan pertahun didapatkan pengambilan keuntungan untuk mencapai BEP bernilai positif dengan mengambil sebesar 20\% dari setiap layanan yang diberikan. Perhitungan pengambilan besaran revenue stream dilakukan melalui komparasi sebesar 5\%, 10\%, 15\% dan $20 \%$. Berdasarkan perhitungan yang dilakukan angka revenue stream sebesar 20\% BEP sebesar $11 \%$ atau bernilai positif atau feasible untuk melanjutkan pengembangan proyek Terampil.

\section{Unfair Advantage atau Keadilan yang Tidak Adil}

Blok yang berisi informasi bahwa produk bisnis yang dihasilkan sulit untuk dicopy atau ditiru oleh orang lain. Blok ini dapat diisi dengan mencamtumkan anggota tim yang tidak mungkin dimiliki oleh organisasi lain hingga teknologi yang tidak dapat ditiru oleh organisasi lain.

\section{a. Fakta Permasalahan}

Saat ini, Terampil belum memiliki hal yang tidak dapat ditiru dan dicopy sehingga blok ini tidak dapat diisi dan dikosongkan

\section{b. Pemodelan Bisnis dengan Lean Canvas}

Lean canvas merupakan salah satu tools yang dapat digunakan untuk penggambaran model bisnis terhadap bisnis yang belum dijalankan [11]. Lean canvas cocok untuk digunakan untuk penerapan waktu dalam kurun waktu tactical yaitu satu sampai tiga tahun kedepan.

Setelah melakukan proses identifikasi masalah calon pelanggan spesifik hingga mendapatkan usulan dari setiap proses yang dilakukan, maka hasil yang telah didapatkan pada customer creation digunakan sebagai acuan pengembangan model bisnis Terampil. Kebutuhan pelanggan yang diidentifikasi dapat menciptakan model bisnis yang dinamis untuk diterapkan pada proyek bisnis Terampil. Pengembangan model bisnis dilakukan secara beruntun sesuai dengan tahapan yang telah dijelaskan oleh [8] dan [7], diawali dengan mengidentifikasi masalah yang sedang dihadapi oleh calon pelanggan untuk mengetahui kebutuhan, menentukan unique value propositon berdasarkan permasalahan dan kebutuhan yang telah didapatkan, hingga menentukan saluran untuk menjangkau pelanggan lain untuk menggunakan Terampil. Ketiga elemen terpenting ini memiliki turunan bangunan blok lainnya problems diturunkan menjadi solution yang ditawarkan atas permasalahan yang ada. Kemudian unique value proporsition akan digunakan untuk menarik minat customers segment melalui keterbaharuan yang ditawarkan. Sementara channel atau saluran mempengaruhi key metrics yang merupakan harapan tim pengambang terhadap bisnis Terampil satu sampai tiga tahun kedepan. Setelah itu, penentuan cost structure didasarkan pada kebutuhan pengembangan Terampil mulai dari variable cost hingga fixed cost. Keberlanjutan layanan pada Terampil bergantung pada revenue stream yang diterapkan. Berdasarkan hasil perhitungan yang telah dilakukan, Terampil membutuhkan $20 \%$ dari setiap transaksi layanan yang disediakan agar dapat bertahan dan memberikan layanan yang baru.

Gambar 3 berikut ini adalah lean canvas yang dibuat berdasarkan analisis pada tahapan customer creation. Lean canvas ini merupakan hasil yang dapat digunakan untuk pengembangan model bisnis Terampil 


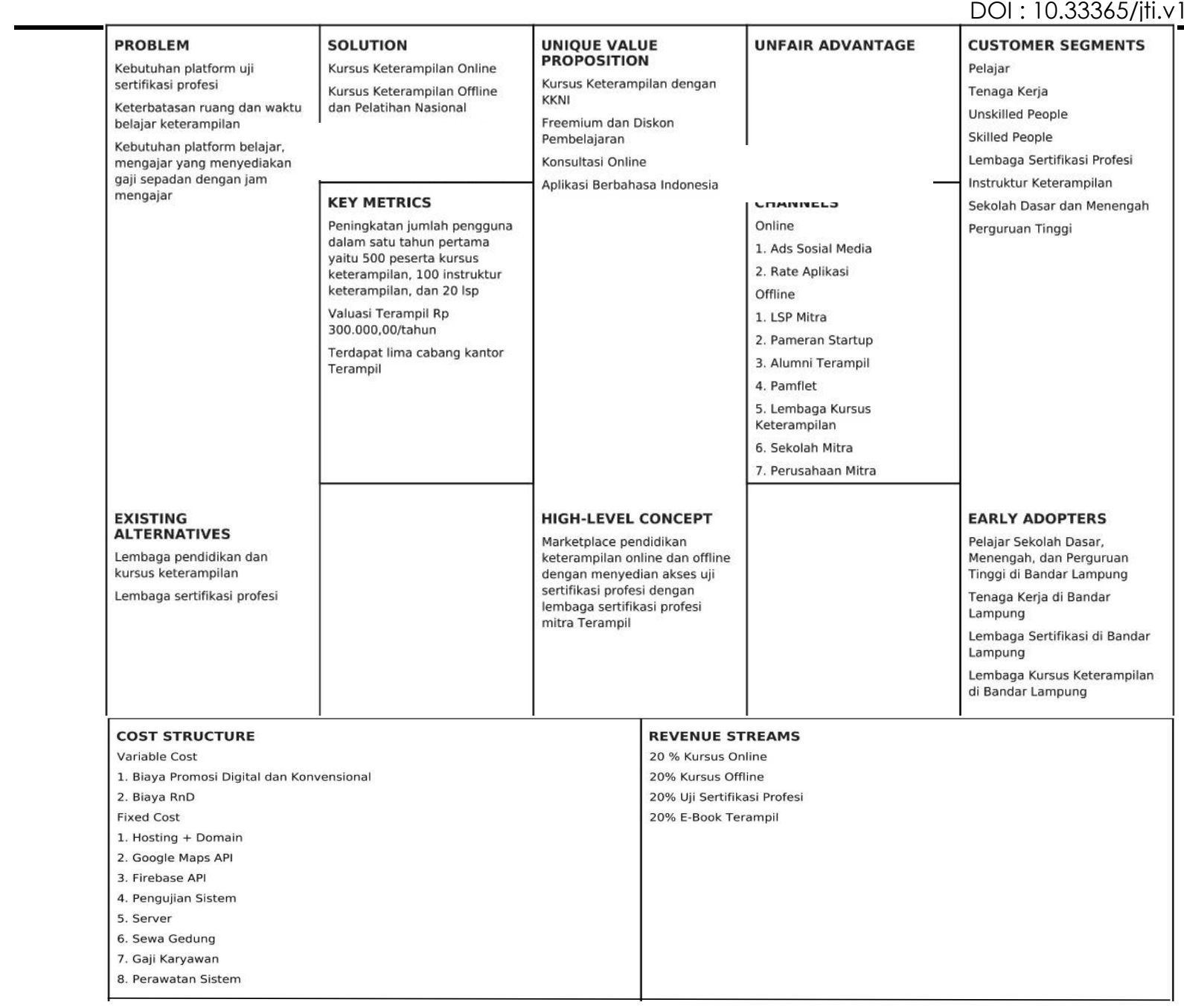

Gambar 3. Penggambaran Pengembangan Model Bisnis Terampil dengan Lean Canvas

\section{c. Validasi Pengembangan Model Bisnis Terampil}

\section{Validasi oleh Expert}

Validasi model bisnis Terampil dilakukan melalui expert judgement. Proses ini telah dilakukan oleh Ibu Dr. Sri Ratna Sulistiyanti selaku Kepala Sentra Inovasi dan Inkubator Bisnis LPPM Universitas Lampung. Hasil yang telah didapatkan adalah sebagai berikut

1. Dampak aplikasi Terampil di masa mendatang lebih memudahkan para pencari sertifikasi keterampilan, karena kemudahan yang diberikan melalui aplikasi berbasis mobile dan terhubung dengan website untuk melakukan proses belajar dan mengajar pendidikan keterampilan hingga melakukan uji sertifikasi profesi

2. Aplikasi Terampil diharapkan dapat menyesuaikan proses bisnis BNSP sebagaui lembaga sertifikasi profesi di Indonesia. Dalam hal ini, diharapkan Terampil dapar bekerjasama dengan banyak LSP agar menjadi marketplace yang menyesuaikan soal uji sertifikasi yang layak sesuai dengan standar yang telah ditetapkan.

3. Aplikasi Terampil memberikan ruang dan waktu yang tak berhingga melalui pembelajaran kursus yang disediakan karena siapapun dapat melakukan pembelajaran keterampilan yang sangat dibutuhkan saat ini dimanapun mereka berada.

4. Pengembangan model bisnis yang sudah dibuat telah memnuhi standar yang diharapkan. Namun, terdapat ambiguitas yang harus dijelaskan terkait segmen pengguna yaitu siswa SD yang mungkin saja belum dapat melakukan uji sertifikasi profesi.

5. Konsep bisnis yang diterapkan untuk Terampil terhadap target pengguna digambarkan dengan alur yang sangat jelas, sehingga pengguna dapat dengan mudah mengakses aplikasi Terampil dan mendapatkan manfaat lebih. Hal ini disebabkan oleh tersedianya materi yang dipersiapkan untuk uji kompetensi dan latihan uji kompetensi berdasarkan KKNI yang ada di BNSP. Selain hal tersebut pengguna juga bisa mendapatkan sertifikat keterampilan dan sertifikat kompetensi, apabila dinyatakan lulus uji keterampilan dan profesi dengan LSP mitra Terampil. Uji keterampilan tidak dilakukan pada ruang dan waktu khusus namun dapat dilakukan dimanapun dan kapanpun

2. Kaitan Hasil Validasi dengan Rekomendasi Solusi dan Model Bisnis 
Keterkaitan hasil validasi yang telah didapatkan dengan rekomendasi model bisnis Terampil dilakukan untuk memastikan bahwa setiap tahapan yang memberikan solusi untuk pemodelan bisnis telah dilakukan dengan benar. Karena validasi pada dasarnya adalah melakukan kegiatan pemeriksaan untuk mendapatkan hasil yang valid atau bernilai benar. Berdasakan hasil penelitian yang telah didapatkan, untuk melakukan pemodelan bisnis, maka berikut ini adalah keterkaitan validasi dengan rekomendasi model bisnis yang telah dibuat

\section{Validasi 1}

Terampil merupakan marketplace kursus dan sertifikasi profesi yang mampu menjadi solusi atas permasalahan yang sedang dihadapi oleh pengelola LSP, instruktur keterampilan, dan peserta kursus keterampilan.

Selain itu, Terampil memiliki dampak untuk mewujudkan visi pemerintahan Republik Indonesia yaitu SDM Unggul Indonesia Maju serta memanfaatkan keberlimpahan peserta bonus demografi yang akan datang pada 2030 - 2040

\section{Validasi 2}

Dalam melakukan proses pembelajaran, Terampil menggunakan kurikulum KKNI sebagai acuan yang daoat digunakan oleh instruktur keterampilan dalam mebuat konten pembelajarannya. Sehingga soal uji yang akan diterapkan pada proses uji keterampilan Terampil akan mengacu pada kurikulum pemebelajaran tersebut

\section{Validasi 3}

Terampil merupakan aplikasi yang dapat diakses dimanapun dan kapanpun setelah peserta kursus melakukan pembayaran kursus. Terampil menyediakan pembelajaran online berupa video keterampilan yang dibuat oleh para instruktur. Sehingga setelah melakukan pembayaran peserta kursus bebas menggunakan aplikasi Terampil dan memilih kursus yang menjadi minatnya

\section{Validasi 4}

Pelajar Sekolah dasar atau SD merupakan salah satu target pengguna spesifik Terampil, karena bisnis ini menyediakan saran pembelajaran pendidikan keterampilan dan akses uji sertifikasi profesi, sehingga target pelajar SD dipertimbangkan dapat melakukan akses pendidikan keterampilan

\section{Validasi 5}

Konsep bisnis yang didapatkan dan diusulkan merupakan salah satu hasil yang telah didapat berdasarkan penerapan pendekatan customer development model. Sehingga, penerapan atau impelementasi kebutuhan konsep bisnis Terampil dilakukan melalui penyesuaian antara permasalahan dan kebutuhan calon pengguna spesifik.

\section{Kesimpulan}

Pemanfataan pendekatan customer development pada pengembangan model bisnis marketplace pendidikan keterampilan dan sertifikasi profesi telah berhasil menciptakan model bisnis yang sesuai dengan permasalahan dan kebutuhan pelanggan. Model bisnis Terampil digambarkan melalui lean canvas melalui penurunan sembilan blok bangunan yang saling berhubungan. Sehingga pemodelan bisnis yang dilakukan sangatlah padu.

Berdasarkan hasil validasi yang didapat berdasarkan expert judgement yang telah dilakukan, Terampil merupakan marketplace yang memiliki konsep bisnis yang menyesuaikan kebutuhan calon pelanggan. Selain itu, melalui penyediaan akses pendidikan keterampilan dengan waktu dan ruang yang tak berhingga serta mengacu pada kurikulum KKNI Terampil dinilai dapat memberikan dampak yang memudahkan pengguna di masa mendatang

\section{Daftar Pustaka}

[1] antaranews.com, "SDM Unggul Indonesia Maju," antaranews.com, 2019. [Online]. Available: https://www.antaranews.com/infografis/1017556/ sdm-unggul-indonesia-maju. [Accessed: 11-Sep2019].

[2] H. Triana and E. Rosmalia, "Pengembangan Kualitas SDM Indonesia dengan Sertifikasi Profesi," lsp-ipi.org, 2017. [Online]. Available: http://lsp-ipi.org/pengembangan-kualitas-sdmindonesia-dengan-sertifikasi-profesi. [Accessed: 11-Sep-2019].

[3] M. I. Hapsari, "Pengkajian Program Kursus Dan Pelatihan Terkait Dengan Jenis Keterampilan, Sertifikasi Dan Penempatan Lulusan," J. Nonform. Educ., vol. 2, no. 1, p. 72, 2016.

[4] Badan Pusat Statistik, Keadaan Tenaga Kerja Di Indonesia Tahun 2019, no. 41. 2019.

[5] Y. Patriella, "Hanya 2,5\% Pekerja di Indonesia Punya Sertifikat Profesi," 2019. [Online]. Available:

https://ekonomi.bisnis.com/read/20190219/12/890 484/hanya-25-pekerja-di-indonesia-punyasertifikat-profesi.

[6] Bappenas, "Bonus Demografi 2030-2040 Strategi Indonesia Terkait Ketenagakerjaan dan Pendidikan,” 2017.

[7] N. D. Wanodyanti, I. Fahmi, and A. Maulana, "Customer Development Model Dalam Bisnis Jasa Pembelajaran Program English as Second Languange (ESL)," J. Apl. Bisnis dan Manaj., vol. 5, no. 1, pp. 95-108, 2019.

[8] S. Blank, "The Path to Epiphany: The Customer Development Model," in The Four Steps to the Epiphany, K\&S Ranch, 2005, pp. 17-28. 
[9] I. Husnayain and M. K. Mawardi, "Implementasi Lean Canvas Pada Startup Dalam Menghadapi Persaingan (Studi Pada Startup Talangin)," J. Adm. Bisnis, vol. 55, no. 2, pp. 30-38, 2018.

[10] R. Rahman and T. Haryati, "Evaluation of Business Model Development through Customer Development Approach ( Case Study of PT Hijup . com )," Tazkia Islam. Financ. Bus. Rev., vol. 10, pp. 88-107, 2016.

[11] A. Maurya, "Running Lean - A systematic process for iterating your web application from Plan A to a plan that works," O'Reilly Media, p. 240, 2012.

[12] A. Osterwalder, Y. Pigneur, A. Smith, and T. Movement, Business Model Generation. Canada, 2010 . 